\title{
ECOLOGICAL CONDITIONS AND DISTRIBUTION OF GEMOR TREE SPECIES IN CENTRAL AND EAST KALIMANTAN
}

\author{
Wahyu C. Adinugroho ${ }^{1}{ }^{2}$, Kade Sidiyasa $^{1}$, Tati Rostiwati ${ }^{3}$ \\ and Dida Syamsuwida ${ }^{4}$
}

\begin{abstract}
The aim of this study was to determine the ecological conditions and distribution of gemor bark producing tree species at Tuanan village in Kapuas District, Central Kalimantan Province and Long Daliq village in Kutai Barat, East Kalimantan Province. In order to collect adequate vegetation data, several observation plots were laid out by using purposive sampling. Primary and secondary data were collected from the plot areas by observing directly the habitat and its ecological condition of vegetation. It was revealed that the gemor tree species tended to grow well on the habitats which have a thin layer of peat $(<2 \mathrm{~m}), \mathrm{pH} 3-4$ and in a humid climatic condition. Two gemor bark producing tree species were identidfied in the study areas, namely Nothaphoebe coriacea (Kosterm.) Kosterm. and N. umbelliflora Blume. The similarity level of vegetation composition at both sites (Kapuas and Kutai Barat Districts) was low. The tree species richness in the plot areas of Tuanan in Kapuas District, Central Kalimantan (82 species, 57 genera and 28 families) was higher than that found in Long Daliq, Kutai Barat District, East Kalimantan (38 species, 26 genera and 19 families).
\end{abstract}

Keywords: habitat, Nothaphoebe coriacea, Nothaphoebe umbelliflora, trees species composition, vegetation

\section{INTRODUCTION}

Gemor is a vernacular or trade name of gemor-bark-producing tree species (or gemor tree), which belongs to genus Nothaphoebe of the family Lauraceae. The species has been commonly identified as belonging to the genus Alseodaphne in the same family (Effendi et al., 1997; Effendi, 2001; Zulnely and Martono, 2003). Locally they are called as gemor, menuk (Kutai, Dayak Tunjung) or tempulob (Dayak Bahau), which cover Nothaphoebe coriacea and N. umbelliflora. According to Sosef et al. (1998), Nothaphoebe coriacea occurs in Peninsular Malaysia, Singapore and Indonesia (Sumatra and Kalimantan); while Nothaphoebe umbelliflora occurs in Indo-China, Thailand, Peninsular Malaysia, Singapore, Indonesia (Sumatra, Java, Kalimantan) and Papua New Guinea. In Indonesia,

\footnotetext{
${ }^{1}$ Samboja Research Institute for Natural Resource Conservation Technology

Jl. Soekarno-Hatta, Km 38, Samboja, Balikpapan, East Kalimantan

${ }^{2}$ Coresponding Author: Email: wahyu1001@yahoo.com

${ }^{3}$ Center for Forest Productivity Improvement Research and Development.

Jl. Gunung Batu No. 5 Bogor, Indonesia.

${ }^{4}$ Bogor Seed Technology Research Institute

Jl. Pakuan, Ciheuleut, Bogor
} 
the two species are found naturally in swampy forests of Sumatra and Kalimantan. Unfortunately, so far there is no attempt to cultivate these species.

The bark of gemor is used as material for insecticide, hio (a stick used for budha's ritual) and glue (Arsad and Suroto, 1992; Rahmanto et al., 2001; Zulnely and Martono, 2003). In Central Kalimantan, gemor bark has been exploited since 1970's. The areas where abundant gemor trees occured are: (1) Pangkoh village, sub-district of Maliku in Kapuas District, (2) Bantanan village, sub-district of Sebangau in Palangkaraya District, (3) Tumbang Nusa village, sub-district of Jabiren Raya in Pulang Pisau District, (4) Taruna village, also in sub-district of Jabirin Raya, Pulang Pisau District, and (5) Kahayan village, sub-district of Kurun in Gunung Mas District.

The production of gemor bark is commonly estimated based on the size of stem diameter. Based on interview with gemor bark collectors at Taruna village (Jabirin Raya sub-district, Pulang Pisau District, Central Kalimantan Province) proportion of stem diameter to bark is as follows: (1) trees with $8 \mathrm{~cm}$ in diameter produced $10 \mathrm{~kg}$ barks in wet condition, (2) trees with $9-12 \mathrm{~cm}$ in diameter produced $25 \mathrm{~kg}$ barks in wet condition, and (3) trees with $>12 \mathrm{~cm}$ in diameter produced 10 sacks (sack size of 25 $\mathrm{kg}$ ) (Rostiwati, 2008).

There are two varieties of $N$. coriacea producing gemor- barks, i.e. (1) trees having rather dark color barks, which are easy to be peelled off, thick and produce more abundant of sticky-jelly like sap, and (2) trees having yelowish red barks, which are difficult to be peelled off, thiner and produce less sticky-jelly like sap. The population of trees having yellowish red bark is only $20 \%$ of the total number of gemor trees observed in Central Kalimantan Province (Rostiwati, 2008). In most cases, local communities prefer to collect bark of $N$. coriacea rather than $N$. umbelliflora.

According to the Provincial Forestry Service of Central Kalimantan, in 2002 the total production of gemor bark was 39.12 tons and decreased to 4.44 tons in 2003 . The price of dry bark was $\mathrm{Rp} 4000,-\mathrm{kg}^{-1}$ (10 kg of dry bark is equal to $20 \mathrm{~kg}$ of wet bark). Nowadays, to get the trees with diameter above $12 \mathrm{~cm}$ in the forest is almost impossible. The dry barks are transported and sold to bigger companies in Banjarmasin (South Kalimantan) and Palangkaraya (Central Kalimantan) and then to Surabaya (East Java) where the final products are processed.

In general, local communites harvested the gemor's bark by cutting the trees, then peeling them off. The barks are collected from all parts of stems and branches. This technique causes the decline of gemor trees in the wild, and therefore, gemor's bark is no longer a source of income for the local communities. To prevent further decline, planting and cultivating the two tree species are urgently needed. In doing so, it is therefore need to evaluate the ecological conditions and distribution of these species. Information on ecological conditions and distribution of the species, which are currently unavailable, would be very necessary in deciding how planting should be implemented. The objective 
of this study was to examine the ecological conditions and distribution of the gemor species.

\section{MATERIALS AND METHODS}

\section{A. Site Description}

This study was conducted at two sites, i.e. Long Daliq, Kutai Barat District (East Kalimantan Province) and Tuanan, Kapuas District (Central Kalimantan Province), from March to December 2008. These two sites are considered as habitats of gemor in Kalimantan. Forests at Long Daliq are public forests managed by the Dayak Bahau tribe, located at 0000'37.7” N latitude and 115³7’34.7” E longitude. In 1997/1998, gemor trees were often found around the Long Daliq and so many people collected gemor bark at that time. The gemor bark collection stopped by itself due to the harvesting technique by felling. The Tuanan forest is located at $02^{\circ} 09^{\prime} 09.0^{\prime \prime} S$ latitude and $114^{\circ} 26^{\prime} 48.0^{\prime \prime}$ E longitute. Tuanan research station was not far from the Kapuas river flow. This area was formerly a logging concession and was later converted into a conservation area for research activities. The forest type in this area is a secondary peat swamp forest.

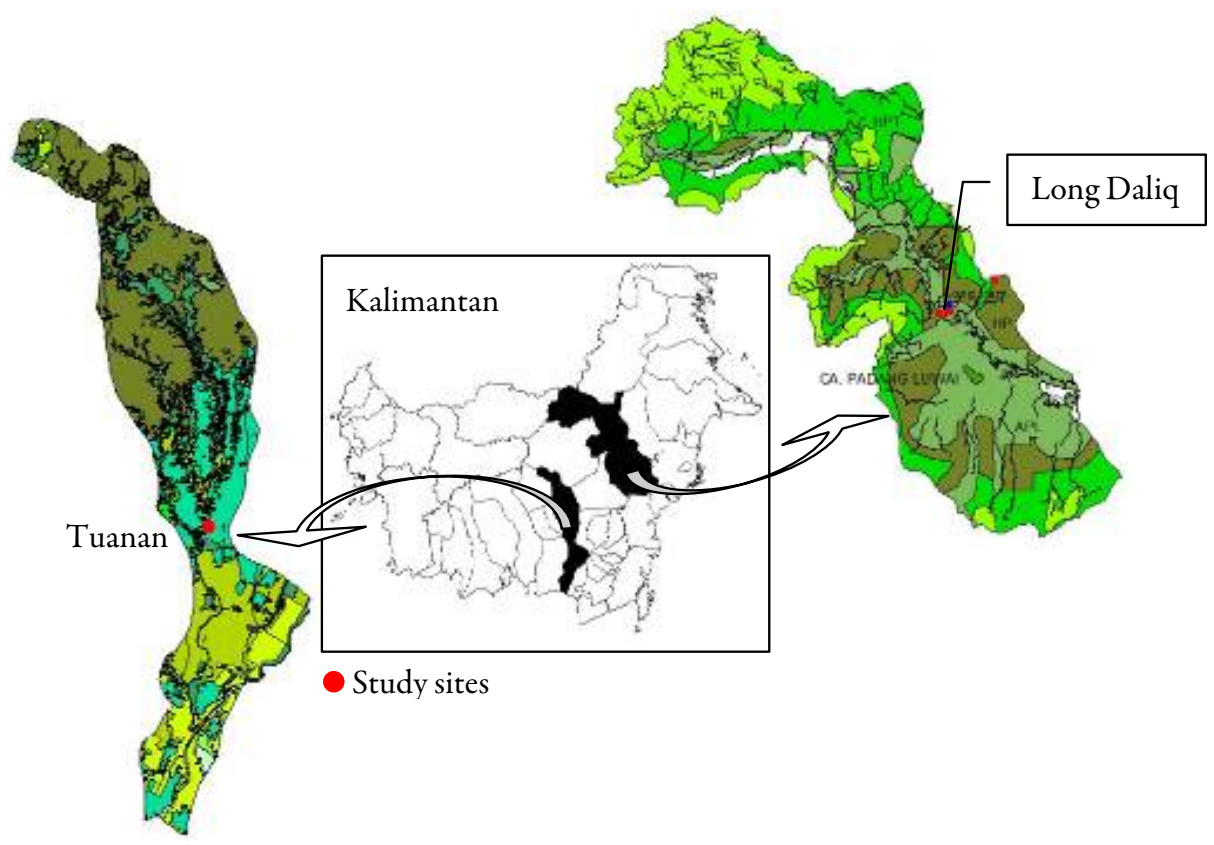

Figure 1. Location of the study sites 


\section{B. Methods}

Data were collected by observing the forest areas directly and establishing observation sample plots to obtain quantitative data of the two species as well as their habitats and ecology. The sample plots were designed purposively at the areas where the gemor trees occurred.

The data collection consisted of:

\section{Primary Data}

These include data on habitat and vegetation (forest community types), forest coverage (open, slightly open, dense forest), micro climate (temperature, humidity), light intensity.

The vegetation analysis was conducted in June and August 2008. A total of 11 square plots ( 5 in Long Daliq and 6 in Tuanan) were laid out randomly. The plot size varies from $20 \mathrm{~m} \times 20 \mathrm{~m}$ for trees, $10 \mathrm{~m} \times 10 \mathrm{~m}$ for poles, $5 \mathrm{~m} \times 5 \mathrm{~m}$ for saplings and $2 \mathrm{~m} \times 2 \mathrm{~m}$ for seedlings. Figure 2 shows the distribution of subplots in each plot. All plants in each square plot were counted and identified to the species level. Diameter at breast height $(\mathrm{DBH})$ and height were measured and recorded. These data were used for computation of vegetation parameters including density, frequency, basal area and Important Value Index (IVI).

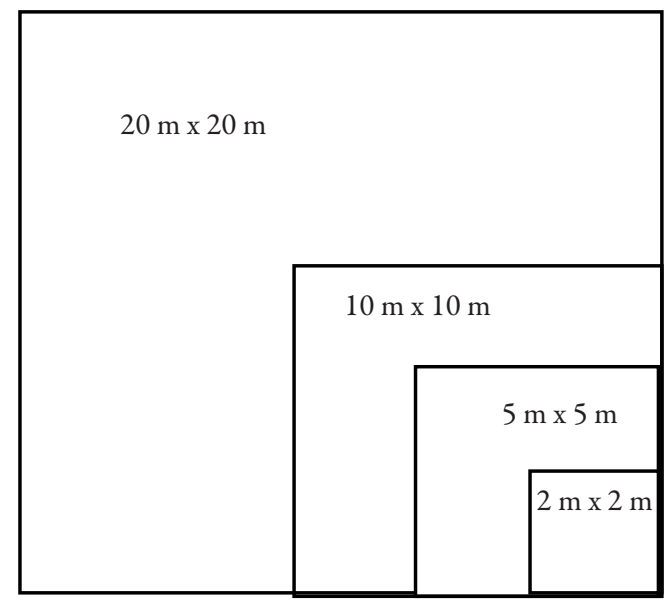

Figure 2. Design of the study plot for vegetation analysis

Herbarium specimens were collected in the field following an international standard for fertile sample. The sterilized sample was also collected as voucher for identification. Identification was done in the Wanariset Herbarium at Samboja, Balikpapan Indonesia. 
The horizontal and vertical vegetation profile were made in a $20 \mathrm{~m} \mathrm{x} 40 \mathrm{~m}$ plot for Long Daliq site.

Destruetive sampling method was used to take soil sample. Soil samples were taken in two depth levels, i.e., top soil $(0-20 \mathrm{~cm})$ and sub soil $(20-40 \mathrm{~cm})$. Five points of soil samplings were composited in each plot, a total of 6 soil sampling plots ( 3 in Long Daliq and 3 in Tuanan) were established.

\section{Secondary Data}

These includes site biophysics (topography, geographical position, soil condtion type, texture and soil fertility). Information following some literature studies were also compiled to support the findings.

\section{Data Analysis}

The IVI for the species was determined as the sum of the relative density, relative frequency and relative dominance (Soerianegara and Indrawan, 1998). The species diversity index $\left(\mathrm{H}^{\prime}\right)$ was determined using Shannon-Wiener index (Shannon and Weaver, 1949). The species richness index $(\mathrm{R})$ was determined using Margalef formula (Margalef, 1958). Concentration of dominance was measured by Simpson's index (Simpson, 1949; Misra, 1980). Association of gemor with other species was analized by Ochiai index formula (Misra, 1980; Ludwig and Reynolds, 1988). Jaccard index was calculated for indicating similarity of vegetation composition within the habitat of gemor at Long Daliq and Tuanan.

Species richness index:

$$
\mathrm{R}=\frac{\mathrm{S}-1}{\mathrm{Ln}(\mathrm{NO})}
$$

where $\mathrm{R}$ is species richness index, $\mathrm{S}$ is number of species and $\mathrm{NO}$ is total number of individual

Species diversity index:

$$
\mathrm{H}^{r}=-\Sigma\left[\frac{\mathrm{ni}}{\mathrm{N}} \log \frac{\mathrm{ni}}{\mathrm{N}}\right]
$$

where $\mathrm{H}^{\prime}$ is spesies diversity index, ni is IVI species-i, and $\mathrm{N}$ is total IVI Species dominance index: 


$$
\mathrm{C}=\Sigma\left(\frac{\mathrm{ni}}{\mathrm{N}}\right)^{2}
$$

where $\mathrm{C}$ is species dominance index, $\mathrm{ni}$ is IVI spesies- 1 , and $\mathrm{N}$ is tatal IVI

Ochiai index:

$$
\begin{aligned}
& 0 i=\frac{a}{(\sqrt{a+b})(\sqrt{a+c})} . \\
& \nabla i=\frac{a}{a+b+c} 100 \% \ldots . . .
\end{aligned}
$$

where $\mathrm{a}$ is sum of plot discovered species $\mathrm{A}$ and $\mathrm{B}, \mathrm{b}$ is sum of plot discovered species $\mathrm{A}$ but not species $B$, and $c$ is sum of plot discovered species $B$ but not species $A$

Primary and secondary data were tabulated, classified and analyzed. Soil samples were analyzed at the Soil Laboratory, Soil Research Institute of the Ministry of Agriculture, Bogor.

\section{RESULTS AND DISCUSSION}

\section{A. Botanical Description}

Based on herbarium specimens collected in the field, two species of gemor trees were identified, namely Nothaphoebe coriacea (Kosterm.) Kosterm. and Nothaphoebe umbelliflora Blume. These species belong to the family Lauraceae. The difference between these two species can be recognized from the color and thickness of the inner bark, which is pale yellow and thicker in $N$. coriacea and reddish in $N$. umbelliflora. The total height of the $N$. coriacea may reach up to $23 \mathrm{~m}$ and the stem diameter reaches $40 \mathrm{~cm}$. They grow well in peat swamps with the depth up to $2.5 \mathrm{~m}$ (Whitmore et al., 1990) (Figure 3). 


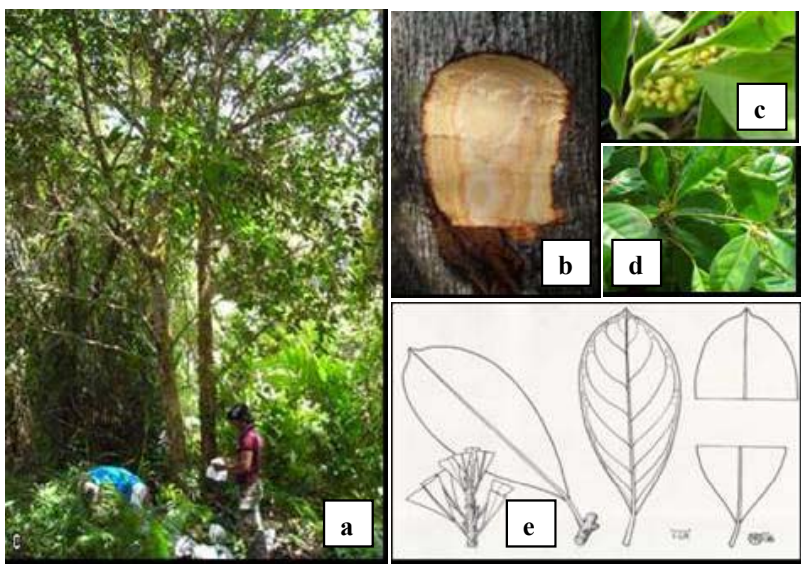

(photo : W.C. Adinugroho, line drawings : Priyono)

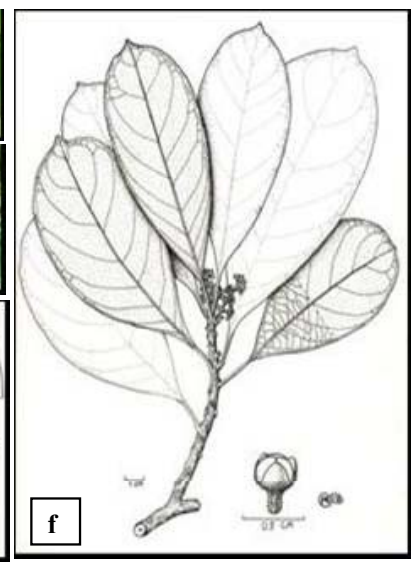

Figure 3. Pictures of Nothaphoebe coriacea (Kosterm.) Kosterm : (a) trees, (b) bark, (c) flowers, (d) leaves, (e) \& (f) leaves with buds

\section{B. Vegetation}

Survey of vegetation in the natural habitat of gemor tree species at Long Daliq (East Kalimantan) and Tuanan (Central Kalimantan) found that there were 38 tree species in the sample quadrats $(0.2 \mathrm{Ha})$, which belong to 26 genera and 19 families, and 82 species which belong to 57 genera and 28 families $(0.24 \mathrm{Ha})$, respectively. The IVI of the most common trees species at every level of growth (seedlings, saplings, poles and trees) within the forest vegetation at both locations are shown in Table 1.

Species richness index value gives an illustration on the number of species (diversity) found compared to the number of individuals (density), with a higher value index of a species means that the species was found in a greater number in the area. Dominance Index Value features the pattern of species dominance in a certain area; a high value of dominance indicates that such areas are dominated by one species. Meanwhile, diversity index (Shannon index) represents the diversity of plant species available in certain areas. In a natural ecosystem, a low dominance index value is good. On the contrary, a high value of diversity index is desirable, as it means that when a high point of species diversity is achieved then the level of ecological stability would be gained. The richness, dominancy and species diversity index at various levels of vegetation growth within habitat of gemor trees are presented in Table 2. 
Table 1. The most common trees species based on the Importan Value Index (IVI) at every stages of vegetation growth in Long Daliq and Tuanan sites

\begin{tabular}{|c|c|c|}
\hline Location & Stages of growth & The most common tree species and its IVI (in bracket) \\
\hline \multirow{4}{*}{ Long Daliq } & Seedlings & $\begin{array}{l}\text { Syzygium sp. } 1 \text { (55.71\%), Horsfieldia sp. (41.43\%), } \\
\text { Stemonurus scorpioides Becc. (34.29\%) }\end{array}$ \\
\hline & Saplings & $\begin{array}{l}\text { Sizygium sp1. (47.67\%), Stemonurus scorpioides Becc. } \\
\text { (18.43\%), Blumeodendron tokbrai Kurz ex J. J. Smith } \\
\text { (15.90\%), Palaquium sp.(15.62\%), Sizygium tawahense } \\
\text { (Korth.) Merr. \& Perry (15.59\%), Dacryodes cf. incurvata } \\
\text { (Engl.) H. J. Lam (15.49\%), Nothaphoebe coriacea (Kosterm.) } \\
\text { Kosterm. (14.73\%) }\end{array}$ \\
\hline & Poles & $\begin{array}{l}\text { Lithocarpus sp1. (52.24\%), Blumeodendron tokbrai Kurz ex J. } \\
\text { J. Smith (37.30\%), Macaranga pruinosa Muell. Arg. (27.20\%) }\end{array}$ \\
\hline & Trees & $\begin{array}{l}\text { Shorea teijsmanniana Dyer ex Brandis }(70.11 \%) \\
\text { Horsfieldia sp. (52.67\%), Diospyros sp1. (28.54\%) }\end{array}$ \\
\hline \multirow{4}{*}{ Tuanan } & Seedlings & $\begin{array}{l}\text { Macaranga puncticulata Gage (30.02\%), Ixora sp. (27.70\%), } \\
\text { Ardisia sp. (13.74\%), Tetramerista glabra Miq. (11.52\%) }\end{array}$ \\
\hline & Saplings & $\begin{array}{l}\text { Tetramerista glabra Miq. (18.70\%), Syzygium sp.1 (16.05\%), } \\
\text { Syzygium sp.2(12.25\%) }\end{array}$ \\
\hline & Poles & $\begin{array}{l}\text { Nothaphoebe coriacea (Kosterm.) Kosterm. (30.04\%), Pala- } \\
\text { quium sp.1 (25.42\%), Shorea teijsmanniana Dyer ex Brandis } \\
(20.12 \%)\end{array}$ \\
\hline & Trees & $\begin{array}{l}\text { Koompassia malaccensis Maing. ex Benth. (46.0\%), Diospyros } \\
\text { sp.1 (37.46\%), Mussaendopsis beccariana Baill. (25.34\%) }\end{array}$ \\
\hline
\end{tabular}

Table 2. Species richness (R), diversity $\left(\mathrm{H}^{\prime}\right)$ and dominance $(\mathrm{C})$ index at various levels of vegetation growth as habitat of gemor trees in Long Daliq and Tuanan sites

\begin{tabular}{lcccccc}
\hline \multirow{2}{*}{$\begin{array}{c}\text { Growth } \\
\text { stages }\end{array}$} & \multicolumn{5}{c}{ Location } \\
\cline { 2 - 7 } & \multicolumn{7}{c}{ Long Daliq } & \multicolumn{3}{c}{ Tuanan } \\
\cline { 2 - 7 } & $\mathrm{R}$ & $\mathrm{H}^{\prime}$ & $\mathrm{C}$ & $\mathrm{R}$ & $\mathrm{H}^{\prime}$ & $\mathrm{C}$ \\
\hline Seedlings & 2.27 & 0.79 & 0.18 & 4.79 & 1.22 & 0.07 \\
Saplings & 6.50 & 1.37 & 0.06 & 11.72 & 1.71 & 0.02 \\
Poles & 4.30 & 1.12 & 0.09 & 7.20 & 1.39 & 0.05 \\
Trees & 2.94 & 0.98 & 0.13 & 5.19 & 1.20 & 0.08 \\
\hline
\end{tabular}


Ochiai index (Oi) formula (Misra, 1980; Ludwig and Reynolds, 1988), revealed that gemor trees in Long Daliq, East Kalimantan were associated mainly with Horsfieldia sp. $(\mathrm{Oi}=1)$, Mezzettia parviflora Becc. $(\mathrm{Oi}=1)$, Shorea teysmanniana Dyer ex Brandis $(\mathrm{Oi}=1)$, Sizygium sp.1 (Oi=1), Stemonurus scorpioides Becc. ( $\mathrm{Oi}=1)$, Dacryodes $c f$. incurvata (Engl.) H. J. Lam (Oi=0.80), Lithocarpus sp.1 ( $\mathrm{Oi}=0.80)$, Litsea angulata Blume (Oi=0.80) and Palaquium sp. ( $\mathrm{Oi}=0.80)$. Meanwhile, in Tuanan, Central Kalimantan, gemor trees were associated well with Diospyros sp.1 (Oi=1), Ilex sp. ( $\mathrm{Oi}=0.83)$, Koompassia malaccensis Maing. ex Benth. $(\mathrm{Oi}=0.83)$, Neoscortechinia kingii (Hook.f.) Pax \& K.Hoffm. (Oi=0.83), Tetramerista glabra Miq. (Oi=0.83), Calophyllum sp. (Oi=0.67), Canarium sp.1 ( $\mathrm{Oi}=0.67)$, Elaeocarpus sp.2 ( $\mathrm{Oi}=0.67)$, Gonystylus bancanus (Miq.) Kurz (Oi=0.67), Palaquium sp.1 (Oi=0.67), Payena lerii (Tejsm. \& Binn.) Kurz (Oi=0.67), Shorea teysmanniana Dyer ex Brandis (Oi=0.67), Syzygium sp.1 (Oi=0.67) and Timonius sp. (Oi=0.67).

The similarity of vegetation composition within the habitat of gemor at Long Daliq and Tuanan based on Jaccard formula was $15.53 \%$. This value indicated the low similarity of vegetation composition at both locations, which might be attributed to the differences of type and depth of peat in both sites.

\section{Forest Structures}

Ecologists have traditionally described the vertical structure of forest stands through profile diagrams. To describe the forest structure of gemor's habitat at the existing condition, a profile diagram for the habitat of gemor in Long Daliq is presented in Figure 4. Vertical vegetation structure consisted of five strata, i.e. stratum $A$ is emergent layer (> $34 \mathrm{~m}$ tall), stratum B is dominant layer $(16-26 \mathrm{~m}$ tall), stratum $\mathrm{C}$ is co-dominant layer $(8-16 \mathrm{~m}$ tall), stratum $\mathrm{D}$ is seedling $(<6 \mathrm{~m}$ tall) and stratum $\mathrm{E}$ is ground cover. The canopy top (emergent layer) is formed by Shorea sp., Palaquium sp. and Diospyros sp. Canopy of Lithocarpus sp., Shorea parvifolia, Gluta renghas, Mezettia parviflora formed the dominant layer. The co-dominant layer is formed by Blumeodendron tokbrai, Sindora wallichii, Sandoricum koetjape, Stemonurus scorpioides, Litsea angulata, Dacryodes rostrata, Macaranga puncticulata, Lithocarpus, Sizygium. Gemor trees in Long Daliq occur in the lower stratum (D) where the species mostly grow as sapling, although poles are dominant in Tuanan (Table 1). This condition also indicated that up to this level, gemor still survived and grew well under shading. 


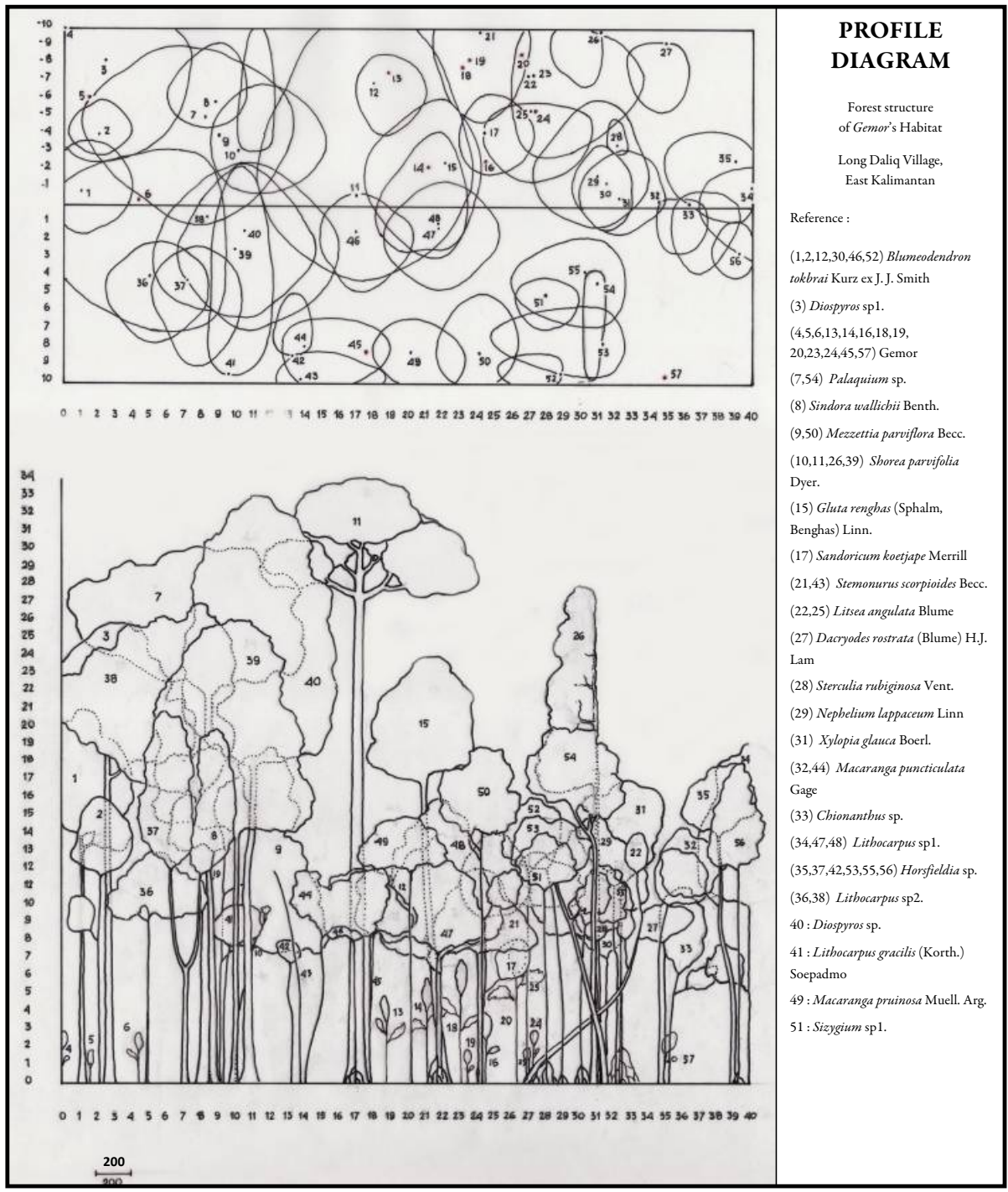

(Line drawing by: Priyono)

Figure 4. Vegetation profile at the gemor habitat in Long Daliq, East Kalimantan

Forest structure can also be described through the distribution of diameter. The result of this study suggest that the curve of diameter distribution in this site did not form a "J" inverted (Figure 5), which indicate that the occurence of disturbances might have impacted on forest regeneration. 


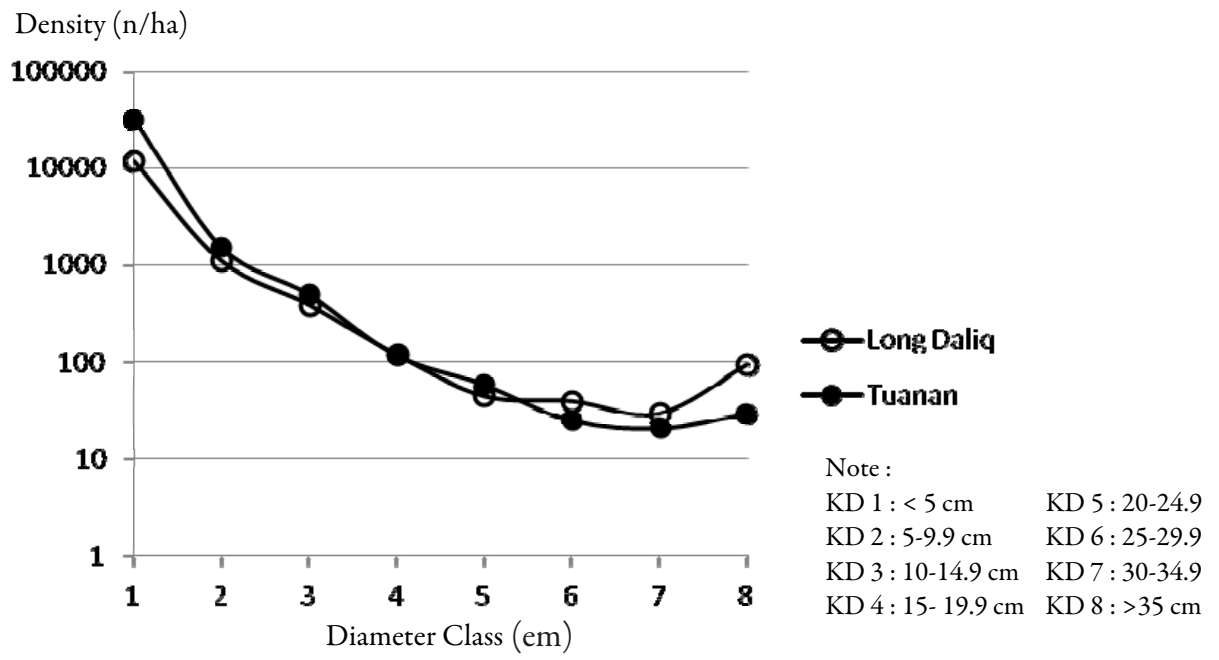

Figure 5. Density (N/ha) by diameter class

\section{Natural Regeneration of Gemor}

One important factor supporting the species sustainability in natural forests is the existence of natural regeneration in a huge number and evenly distributed. The observation taken for gemor regeneration revealed that seedlings were rarely found In Tuanan (only 2 seedlings were found in 6 plots $\left(833\right.$ ind ha $^{-1}$ ) and were absent in Long Daliq observation plots. In the two sites, however, there were buds sprouted at the base (stump) of the cut trees (Figure 6). This condition was also reported by Effendi (2001) who found tree stumps with 3 - 4 buds sprouted. Therefore, it might be assumed that there was a potential to propagate plant by coppicing. Silvicultural system with coppice as planting materials for plantation has been practiced succesfully in England to produce small logs, stem barks and fuel woods (Smith, 1962). In Indonesia, coppice system has been adopted by Perum Perhutani (Government Timber Estate Enterprise) in Nganjuk, East Java, to develop teak plantation. Moreover, people also do cultivate sengon (Paraserianthes falcataria) from copices; they keep the sprouted buds on the stumps of harvested sengon and allow them to grow to maturity for future harvesting. 

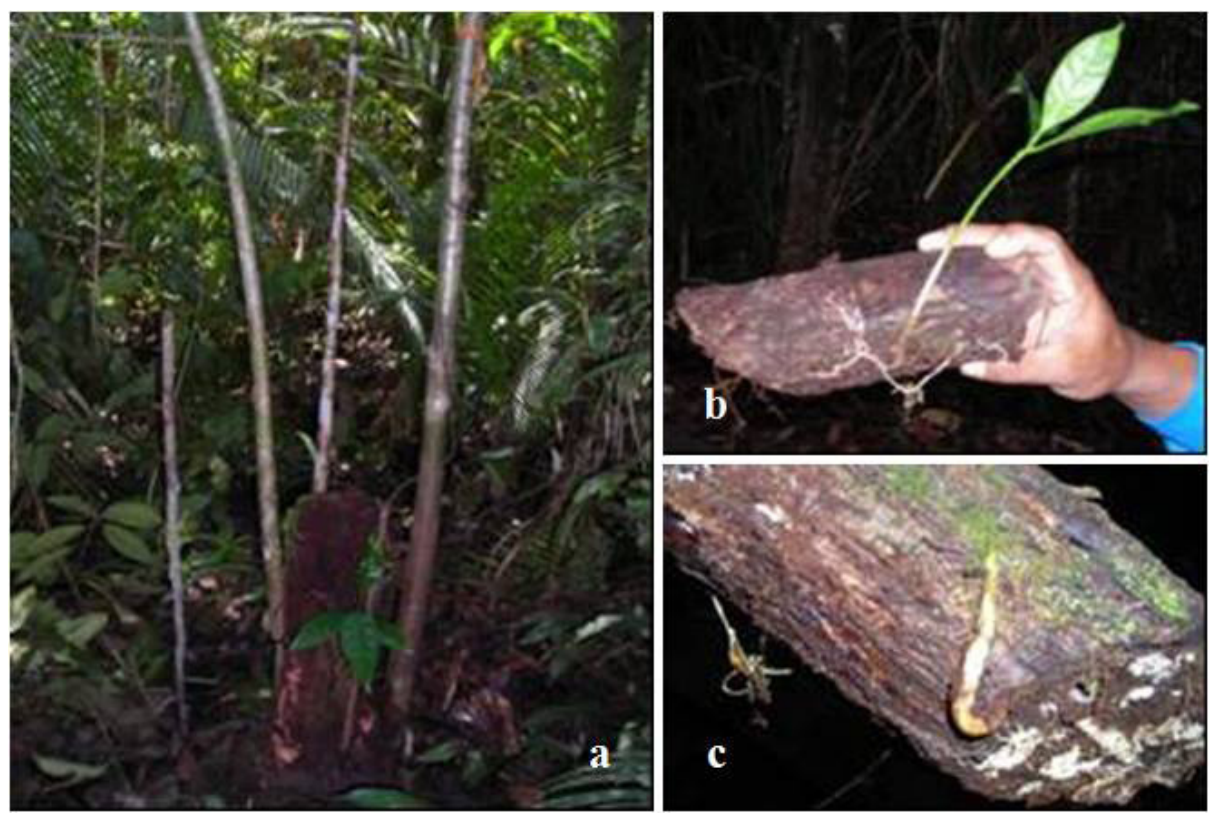

(photo : W.C. Adinugroho)

Figure 6. Sprouted coppices in gemor tree : (a) Long Daliq, (b) and (c) Tuanan

\section{E. Distribution of Gemor}

There were no gemor trees with large diameter found in the observed areas, mostly only coppices from trees that have been harvested were found. The tend to grow in cluster at certain points (Figure 7 ).

\section{F. Ecological Condition}

1. Microclimate

Growth and reproduction of plants are strongly related to environmental factors. Climatic characteristic of the habitat of gemor is catagorized as humid tropical climate, with the peak rainfall takes place in April and the lowest in August, as well as no dry season occurs or there should be at least 7 days rainfall within a month over the year. Rainfall data in Long Iram (Meteorological Station) in the year of 1900 to 1960 showed that gemor habitats have a high annual rainfall of $3579 \mathrm{~mm} \mathrm{yr}^{-1}$ in average. However, within the last decade, weather conditions have been irregular caused by climatic change impacts. In 2005, the rainfall was $2501 \mathrm{~mm} \mathrm{yr}^{-1}$, the peak rainfall occurred in December 
and August (Kecamatan Long Iram dalam angka 2006) Observation results for the environmental condition of the area is presented in Table 3.

Table 3. Environmental condition of gemor's habitat at Long Daliq, East Kalimantan

\begin{tabular}{ll}
\hline \multicolumn{1}{c}{ Parameter } & \multicolumn{1}{c}{ Condition } \\
\hline Topography & Flat, occasional water logging \\
Temperature & $21.3-32{ }^{\circ} \mathrm{C}$ \\
Humidity & $88 \%-99 \%$ \\
Light Intensity & $3 \%-5 \%(540$ lux -980 lux ; open area : \\
Forest community type & 20000 lux $)$ \\
\hline
\end{tabular}

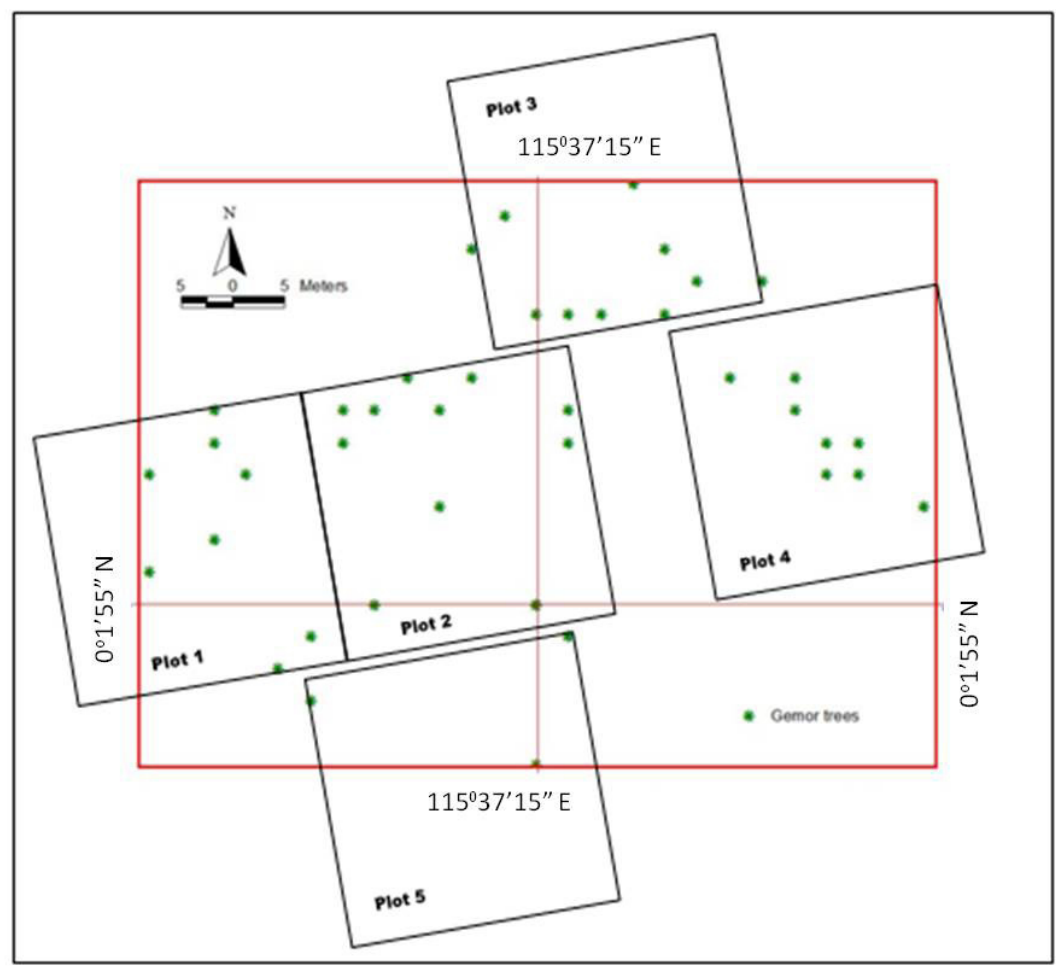

Figure 7. Distribution of gemor in the observation plots at Long Daliq, East Kalimantan 


\section{Soil Condition}

Soil condition similar to the original habitat is one of the supporting factor for succesfull planting. Soil type of gemor's habitat found in the observation plots was peat soil with the $\mathrm{pH}$ of $3-4$ and peat depth of $1-2 \mathrm{~m}$, although Whitmore et al.(1990) described that gemor trees grow well in peat swamps with the depth of $2.5 \mathrm{~m}$. Gemor can grow well in a peat soil with the content of alkalie (e.g. $\mathrm{Ca}, \mathrm{Mg}, \mathrm{K}, \mathrm{Na}$ ) and saturated alkalie were low. The content of $\mathrm{Al}$ was mostly low to medium and became fewer following the decrease of soil $\mathrm{pH}$, different to the content of $\mathrm{H}^{+}$which was being increased. As peat soil, gemor's habitat has a high content of $\mathrm{C}$ and $\mathrm{N}$ total; however, most of them were unavailable to plants due to a high ratio of $\mathrm{C} / \mathrm{N}$. The thicker peat, lower content of $\mathrm{K}_{2} \mathrm{O}$ and $\mathrm{P}_{2} \mathrm{O}_{5}$ ashes, $\mathrm{Ca}$ and $\mathrm{Mg}$ contents decreased and soil reaction became more acid. The acid peat soil (low $\mathrm{pH}$ ) was not always followed by the high $\mathrm{Al}^{2+}$ content (changeable Aluminum) as it happens in mineral soils. This might occur once the source of $\mathrm{Al}$ or soil minerals in an organic soil were present in a small amount. The cation exchange capacity (CEC) in peat soil was greater than in mineral soils. CEC value of peat soils was generally higher than in mineral soils and much greater in line with the increasing organic matter content. The value of CEC plays an important role in soil management and could be acted as indicator of soil fertility. The condition of chemical properties of the soils can be seen in Table 4 .

Table 4. Chemical properties of the soils at two locations of gemor habitats in Long Daliq and Tuanan

\begin{tabular}{|c|c|c|c|c|c|c|c|c|c|c|c|c|c|c|}
\hline \multirow{5}{*}{ Location } & \multirow{4}{*}{$\begin{array}{c}\begin{array}{c}\text { Horizon } \\
\text { layer }\end{array} \\
\text { Above- } \\
\text { Below }\end{array}$} & \multirow{2}{*}{$\begin{array}{c}\text { Ex- } \\
\text { tract } \\
1: 5 \\
\mathrm{PH}\end{array}$} & \multicolumn{12}{|c|}{ Dry Sample $105^{\circ} \mathrm{C}$} \\
\hline & & & \multicolumn{3}{|c|}{ Organic Matter } & \multirow{2}{*}{\multicolumn{2}{|c|}{-Bray $1 \begin{array}{c}\text { Mor- } \\
\text { gan }\end{array}$}} & \multirow{3}{*}{$\mathrm{Ca}$} & \multicolumn{4}{|c|}{$\begin{array}{l}\text { Cation Changes Value } \\
\left(\mathrm{NH}_{4} \text {-Acetat } 1 \mathrm{~N}, \mathrm{pH} 7\right)\end{array}$} & \multicolumn{2}{|r|}{ KCL $1 \mathrm{~N}$} \\
\hline & & \multirow[t]{2}{*}{$\mathrm{H}_{2} \mathrm{O}$} & $\begin{array}{c}\text { Walk\& } \\
\text { Black } \\
\end{array}$ & $\begin{array}{l}\text { Kjel- } \\
\text { dahl }\end{array}$ & \multirow[t]{2}{*}{$\mathrm{C} / \mathrm{N}$} & & & & $\mathrm{Mg}$ & K & $\mathrm{Na}$ & Total & CEC & $\mathrm{Al}^{3+}$ \\
\hline & & & $\mathrm{C}$ & $\mathrm{N}$ & & \multicolumn{2}{|c|}{$\mathrm{P}_{2} \mathrm{O}_{5} \quad \mathrm{~K}_{2} \mathrm{O}$} & & & & & & & \\
\hline & $\mathrm{cm}$ & & \multicolumn{2}{|c|}{..... $\%$-.... } & & \multicolumn{2}{|c|}{-.--ppm --.-- } & & \multicolumn{4}{|c|}{-..- $\operatorname{cmol}(+) / \mathrm{kg}-\ldots$} & & $\operatorname{cmol}(+) / k g$ \\
\hline Tuanan & $0-20$ & 3.1 & 54.48 & 1.22 & 45 & 13.4 & 292 & 3.56 & 2.69 & 0.58 & 0.13 & 6.96 & 178.83 & $0.89 \quad 16.65$ \\
\hline Village & $20-40$ & 3.1 & 56.83 & 1.12 & 51 & 9.9 & 231 & 4.35 & 1.15 & 0.46 & 0 & 5.96 & 104.76 & $0.95 \quad 17.89$ \\
\hline Long Daliq & $0-20$ & 3.3 & 49.44 & 1.24 & 40 & 8.6 & 351 & 3.34 & 0.64 & 0.69 & 0 & 4.67 & 50.52 & $2.48 \quad 8.09$ \\
\hline Village & $20-40$ & 3.2 & 64.72 & 0.99 & 65 & 15.3 & 243 & 7.98 & 0.76 & 0.48 & 0 & 9.22 & 38.92 & $3.6 \quad 10.05$ \\
\hline
\end{tabular}

\section{CONCLUSION}

The impact of over-exploitation to the population of Nothaphoebe coriacea (Kosterm.) Kosterm was a limited availability of sapling and poles of this species. The IVI of the sapling and poles were 14.73\% (in Long Daliq, East Kalimantan) and 30.04\% (in Tuanan, Central Kalimantan). 
Different conditions of the Nothapoebe coriacea's habitat in the two research sites (in term of vegetation, soil fertility and the important value index) should unplug different strategies in the conservation and management program. In Long Daliq, it is required to focus on sapling improvement through in-situ conservation activities. Meanwhile, at Tuanan the focus should be on species preservation by collection Nothapoebe coriacea seedlings to be planted through ex-situ conservation program.

\section{REFERENCES}

Arsad, E. and Suroto. 1992. Pengolahan kulit gemor sebagai bahan pemberantas nyamuk jenis bakar. Laporan Balai Penelitian dan Pengembangan Industri Banjarbaru. Balai Penelitian dan Pengembangan Industri Banjarbaru. Banjarbaru. (unpublished report)

Badan Pusat Statistik. 2006. Kecamatan Long Iram dalam angka 2006. Badan Pusat Statistik Kabupaten Kutai Barat, Kalimantan Timur. (unpublished report)

Effendi, R. 2001. Pengaruh pengambilan kulit gemor (Alseodaphne spp.) terhadap kelestarian di Teluk Umpan, Kalimantan Tengah. Duta Rimba 247:10-12.

Effendi, R., M. Amblani, and T. Wahyuni. 1997. Kajian ekonomi produksi kulit kayu pohon gemor (Alseodaphne spp.). Buletin Penelitian Kehutanan 11 (1):7-17.

Ludwig, J.A. and J. F. Reynolds. 1988. Statistical Ecology: A primer on methods and computing. John Willey and Sons. New York.

Margalef, R. 1958. Information theory in ecology. General Systematic 3: 36-71.

Misra, K.C. 1980. Manual of Plant Ecology. Oxford and IBH Publishing Co. New Dehli.

Rahmanto, R.G.H., D.I. Fauzi. and A. Iskandar. 2001. Gemor, hasil hutan bukan kayu dari Kalimantan Timur. Tajuk Tropika I (2): 10-11.

Rostiwati, T. 2008. Laporan hasil penelitian silvikultur tanaman penghasil hasil hutan bukan kayu. Pusat Litbang Hutan Tanaman (unpublished report).

Shannon, C.E. and W. Weaver. 1949. The Mathematical Theory of communication, University Illinois Press, Urbana, Illinois.

Simpson, E.M. 1949. Measurement of diversity. Nature 163: 688.

Smith, D.M. 1962. The Practice of Silviculture. John Wiley \& Son. New York.

Soerianegara, I. and A. Indrawan. 1998. Ekologi hutan. Diktat kuliah. Fakultas Kehutanan - IPB. Bogor

Sosef, M.S.M., L.T. Hong. and S. Prawirohatmodjo. 1998. Plant resources of South-East Asia. Vol. 5 (3); Lesser known timbers. Backhuys Publishers, Leiden. 
Whitmore, T.C., I. G.M. Tantra, U. Sutisna, and K. Sidiyasa. 1990. Tree Flora of Indonesia: Cheklist for Kalimantan. Pusat Penelitian dan Pengembangan Hutan. Bogor.

Zulnely. and D. Martono. 2003. Pemanfaatan kulit gemor (Alseodaphne sp.) sebagai bahan untuk pembuatan anti nyamuk bakar. Jurnal Ilmu \& Teknologi Kayu Tropis $1(1): 12-19$. 